\title{
Chemically modified cellulose as a potential oil adsorbent of contaminated marine ecosystems
}

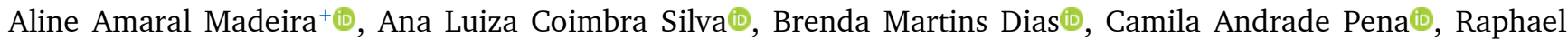
Victor Costa Oliveira

Pontifical Catholic University of Minas Gerais (PUC-MG), 500 Dom José Gaspar Av, Belo Horizonte, Minas Gerais, Brazil

${ }^{+}$Corresponding author: Aline Amaral Madeira, Phone: +55 31 991807451, Email address: madeira.alineamaral@gmail.com

\section{ARTICLE INFO}

Article history:

Received: February 11, 2019

Accepted: February 18, 2020

Published: April 1, 2020
Keywords:

1. marine ecosystems

2. sea oil spill

3. cellulose

4. chemical modification

5. adsorption

\begin{abstract}
Petroleum exploration, as well as environmental impacts descendant of aquatic contaminations involving sea oil spills, foments the development of new technologies of marine ecosystems protection. Acknowledged like the most abundant polymer available today worldwide, cellulose is a linear 1.4- $\beta$ glucan, composed of D-anhydroglucopyranose units, linked together by $\beta$ - $(1 \rightarrow 4)$-glycosidic bonds. In this study, a chemical modification route of the cellulose polymer was accomplished using glycidyl methacrylate and stearin to test its oily adsorption capacity of soybean, diesel, and residual oils. Scanning Electron Microscopy (SEM) and Fourier-Transform Infrared (FT-IR) Analyses were applied to the characterization of the morphological and functional structure of microcrystalline cellulose. The results obtained proved the reach of an average hydrophobicity grade of $78.3 \pm 0.9 \%$ and a mass gain of

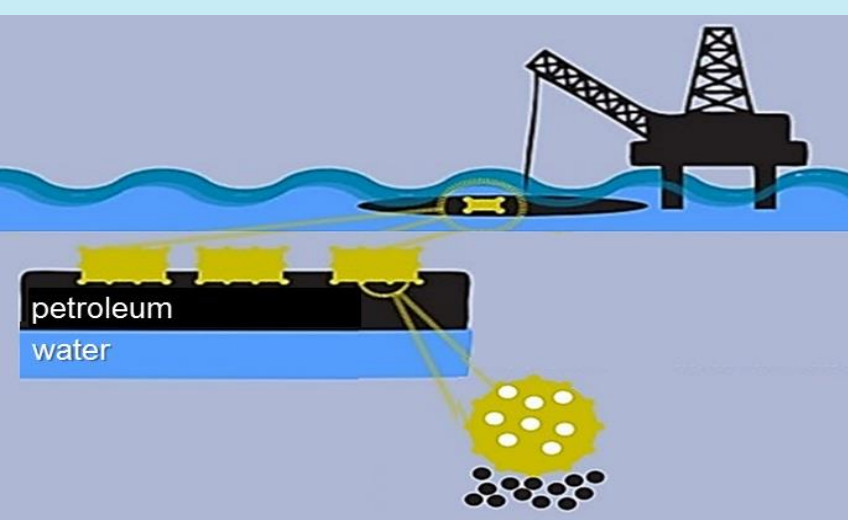

Oil-adsorption into sea petroleum spill.

$\mathrm{MG}=2.89 \%$, suggesting the possible insertion of hydrophobic groups onto the cellulose molecule and corroborating the hypothesis of successful grafting of glycidyl methacrylate and stearin onto the polymer. The oily adsorption tests showed a satisfactory capacity of the modified cellulose to adsorb small amounts of viscous oils, like residual oil.
\end{abstract}

\section{Introduction}

Water resources scarcity associated with the occurrence of accidental contaminations of oil and their derivatives spills, mainly caused by petroleum exploration in the $21^{\text {st }}$ century, are themes which merit investigation and substantiate the continuous research efforts to promote the study and development of new technics or technological improvements in favor of the marine ecosystems environmental protection.

In Brazil, one of the most serious accidents involving the petroleum spill occurred in 2011, in the Campos Basin, where 588 thousand liters of oil were spilled into the sea. On the international scene, the Deepwater Horizon platform's accident, considered by many experts like the worst environmental disaster, occurred in the Gulf
Coast and resulted in a sea oil spill of 780 million liters $^{1-3}$. Every year, 600 thousand tons of oil are spilled into the sea. Petroleum and their products' spills are considered environmental catastrophes that affect the entire marine ecosystem. Fish die from asphyxiation when they come in contact with hydrocarbons and birds suffer from intoxication. Moreover, these tragedies affect coastal communities that survive from fishing, among other deleterious effects for the marine ecosystems ${ }^{4-6}$.

Marine water resources are one of the great world riches. In Brazil, the environmental protection to marine waters is entangled on the Federal Constitution, the Civil Code, and environmental crimes laws, which deals of sea oil contamination, regarding preventive, control and inspection measures ${ }^{7}$. Current Brazilian legislation 
is more punitive than preventive and only came into effect after the impacts caused by environmental accidents that occurred over time with the petroleum exploitation, such as 265/2000 Resolution of the Conselho Nacional do Meio Ambiente, created after the oil spill in Guanabara Bay in $2000^{4,8}$.

Selection of the most appropriate method to contain oil and their derivatives' spills is of crucial importance to minimize the environmental impacts to marine ecosystems. Among the used techniques are controlled combustion, containment barriers' use, skimmers technology, chemical dispersants or absorbent and adsorbent materials' application. Controlled burning is one of the most efficient practices when it comes to removing oil from the sea. However, the method is ecologically unfeasible because, in addition to the release of carbon dioxide, the waste from the combustion of petroleum is highly viscous. If they reach greater depths to the ocean floor, their damage may include environmental damage to water quality and aquatic species. The use of containment barriers and skimmers technology are examples of methods employed that avoid spreading oil beyond the spill origin. It consists of concentrating and directing the oil slick to the region where it is collected, preferably away from the coastal regions. skimmers work as a filtering membrane that collects and separates the oil and water mixture with subsequent oil recovery ${ }^{5,8,9}$.

Another technique that can be used to assist the removal of the oils is the chemical dispersants and absorbent materials use. Dispersants consist of the application of chemicals (surfactants and solvents) that aid in the fragmentation of hydrocarbon chains into smaller molecules. This process facilitates the formation of droplets which are then consumed by naturally occurring bacteria in the aquatic environment. However, this is a process that does not provide oil recovery. The absorbents are indicated to collect all type of oil and derivatives. They can be found in various forms and absorb up to 25 times their own weight 5 .

Adsorption process has been widely used in recent years in the treatment of industrial effluents contaminated by oils, heavy metals, dyes, and other pollutants. It is characterized by the ability of a specific component (adsorbed), dispersed or dissolved in a mixture, to adhere to the surface of a substance, called adsorbent. There are two types of adsorption. Physical adsorption also called physisorption and chemical adsorption called chemisorption. The first occurs when the adsorbent and adsorbate realize inter-molecular interactions of the Van der Waals type. Due to the low strength of these interactions, the process is reversible. However, the chemisorption is an irreversible process, once the adsorbed substance makes chemical bonds with the adsorbent to atomic levels ${ }^{10-13}$.

Currently, several research lines have been developed with an emphasis on the study of new technologies aiming the biodegradable raw materials use and obtaining of products with different properties for various application potentials. Cellulose, a linear 1.4- $\beta$-glucan, is the most abundant polymer available today worldwide. It is a linear syndiotactic homopolymer composed of D-anhydroglucopyranose units, which are linked together by $\beta$-(l $\rightarrow 4)$-glycosidic bonds. Taking the dimer cellobiose as the basic unit, cellulose can be considered as an isotactic polymer of cellobiose (Fig. 1) ${ }^{14}$. Cellulose structure is formed by hydrogen bonds between its hydroxyl groups. Like a result of the supramolecular structure, cellulose presents highly ordered regions, crystalline regions, intermediated by less ordered regions, called amorphous regions. Due to lower stability, amorphous regions are more accessible to attack by reagents and enzymes ${ }^{15}$.

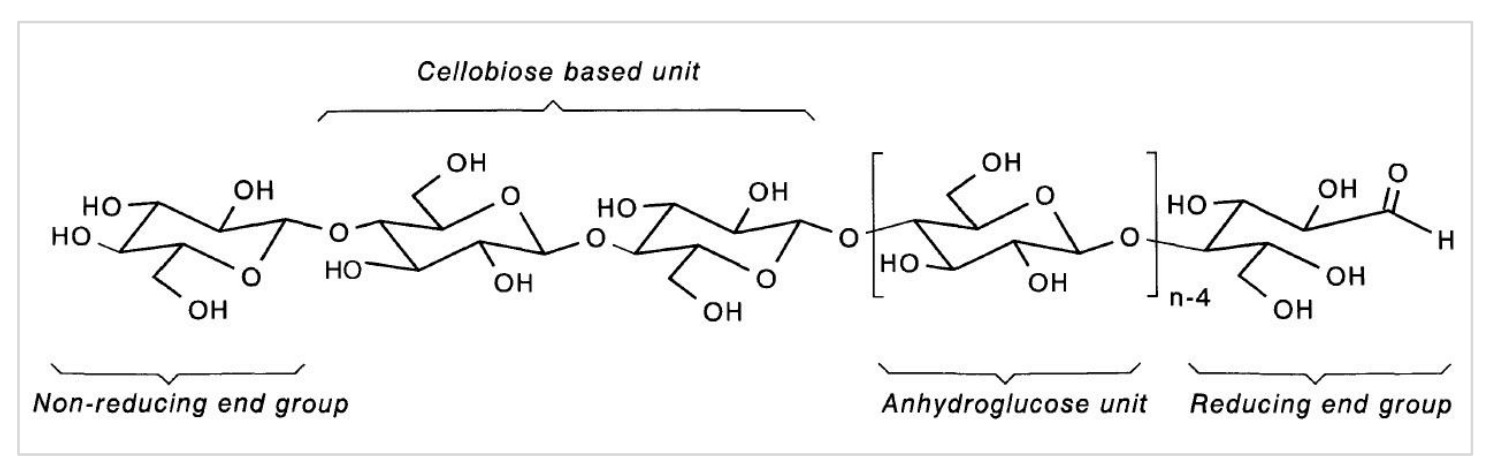

Figure 1. Molecular structure of cellulose $\mathrm{e}^{14}$. 
In microbiology, bacterial cellulose has been applied in the sponges' form in the mining and refining area to collect oil leaks and toxins absorption ${ }^{16}$. In medicine, cellulose has been applied in the development of new hybrid fibers that may have anti-inflammatory, bactericidal, antifungal and cicatrizing properties ${ }^{17}$. In the field of nanotechnology, the nano-fibrillated cellulose obtained by the disintegration of the polymer stands out to have singular physical and mechanical properties, such as high density and high resistance to traction and bursting ${ }^{12}$.

Scientists have developed research in the organic synthesis area, studying different chemical modification routes of cellulose molecule with focus on increasing its adsorption capacity and development of new properties and functionalities ${ }^{18-26}$. Among them, Brum et al. ${ }^{18}$ synthesized cellulose acetate from bean straw using ethanoyl ethanoate as well as pyridine and 1bromo-2.5-pyrrolidinedione as catalysts. The researchers succeeded in the chemical modification, achieving a hydrophobicity percentage of $93.5 \%$ for cellulose acetylated with pyridine and $98.7 \%$ for acetylated cellulose with 1bromo-2.5-pyrrolidinedione. Macedo ${ }^{21}$ proposed the hydrophobization of wood pulp fibers of Pinus elliotti in a study of the influence of oil sorption using triethoxyvinylsilane and ethanoic acid as reagents. The authors obtained physical sorption of more than twenty grams of oil per each gram of modified cellulose. Oliveira ${ }^{23}$ studied the development of oil adsorbent materials by chemical modification of residues from coffee processing consisting of a high content of fibers (cellulose, hemicelluloses, and lignin) with ethanoyl ethanoate and 1-bromo-2.5pyrrolidinedione, reaching adsorption of circa two grams of oil per gram of modified material. Zimmermann ${ }^{24}$ functionalized cellulose using the 2-methylprop-2-enoic acid 2-oxiranylmethyl ester and 1.3-di(octadecanoyloxy) propan-2-yl octadecanoate reagents for use as an oil adsorbent, obtaining a modified material with a hydrophobicity grade of $87 \pm 3 \%$.

In this context, having as motivation the historical of aquatic contaminations involving sea oil spills and their malefic impacts to marine ecosystems, the present article aims to investigate the oily adsorption potential of chemically modified cellulose as a possible alternative of application in environmental remediation of marine ecosystems contaminated by oils.

\section{Experimental}

The present research mobilized the development of following steps: (1) Characterization of a sample of microcrystalline cellulose via scanning electron microscopy (SEM) and Fourier-transform infrared (FT-IR) analyses; (2) Chemical modification of microcrystalline cellulose; (3) FT-IR analysis of chemically modified cellulose; (4) Hydrophobicity and mass gain tests of chemically modified cellulose; (5) Oil adsorption tests of modified cellulose with soybean, diesel, and residual oils.

\subsection{Pre-modification characterization via SEM and FT-IR analyses}

A sample of microcrystalline cellulose in nature (Synth) was atomized using gold $(\mathrm{Au})$ and fixed to the sampler using carbon tape. SEM analysis was accomplished in a scanning electron microscope (Joel, model JSM-IT300). Pellets of other sample of microcrystalline cellulose in nature (Synth) were prepared using potassium bromide $(\mathrm{KBr})$, with the aid of pestle, mortar, and hand press (Shimadzu, model 200-64175). The FT-IR spectrum was obtained in the IR solution software of a spectrometer with $2 \mathrm{~cm}^{-1}$ resolution and 10 scans for sample (Shimadzu, model IRAffinity-1).

\subsection{Chemical modification}

Cellulose was functionalized using glycidyl methacrylate (GMA) and stearin in triplicate based on the procedure reported by Pracella ${ }^{26}$. The analytical reagents were: propanone (Neon); ethanol (Synth); stearin (1.3-di(octadecanoyloxy) propan-2-yl octadecanoate) (Synth); GMA (2methylprop-2-enoic acid 2-oxiranylmethyl ester) (Aldrich Chemistry); hexane (Neon), triethylamine (Anidrol), and distilled water.

The modification montage was made up with the aid of universal support, heating plate, ball condenser, round bottom flask, and thermometer. A solution of triethylamine/GMA (7:3 v:v) was prepared in a $250.0 \mathrm{~mL}$ volumetric flask. $60.0 \mathrm{~mL}$ of this solution and $12.0 \mathrm{~g}$ of dried microcrystalline cellulose, previously weighed on analytical balance (Shimadzu, model AW220), were added to the 
round bottom flask. The chemical reaction was kept under constant stirring at $90{ }^{\circ} \mathrm{C}(363.15 \mathrm{~K})$ for a period of $4 \mathrm{~h}$.

At the end of stirring and heating period, the material was filtered and washed with ethanol and propanone. Then, the flask was transferred to a beaker and was stored at room temperature for $24 \mathrm{~h}$. Subsequently, it was dried in a kiln (Infinit, model EMT-200) and maintained at $100{ }^{\circ} \mathrm{C}$ $(373.15 \mathrm{~K})$ for a period of $4 \mathrm{~h}$. A solution of ethanol/stearin $\left(95: 5 \mathrm{~mL} \mathrm{~g}^{-1}\right)$ was prepared in a
$250.0 \mathrm{~mL}$ volumetric flask. $100.0 \mathrm{~mL}$ of this solution was added to the functionalized cellulose. Next, the modification montage was again made up and the reaction was maintained at $\left(50{ }^{\circ} \mathrm{C}\right) 323.15$ $\mathrm{K}$ for $4 \mathrm{~h}$. After the modification steps, the modified material was filtered again. Figure 2 (step I) shows the reaction scheme for the grafting of GMA onto cellulose (Cell-GMA) and (step II) the reaction scheme for the grafting of stearin onto Cell-GMA (Cell-GMA-Stearin).

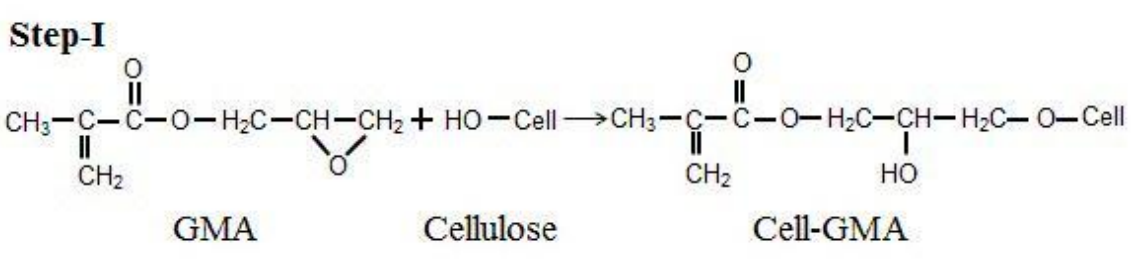

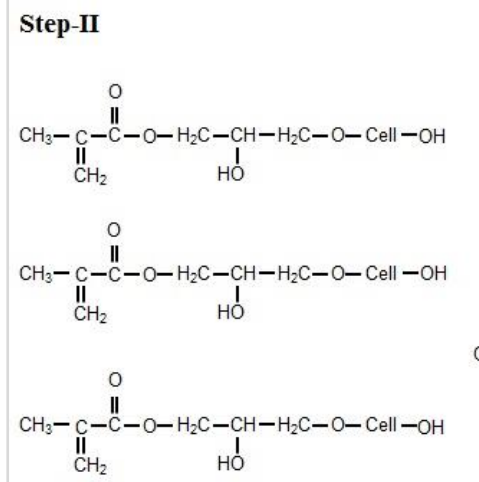

Cell-GMA

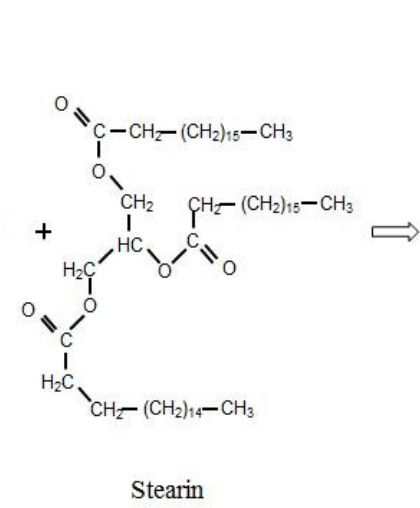

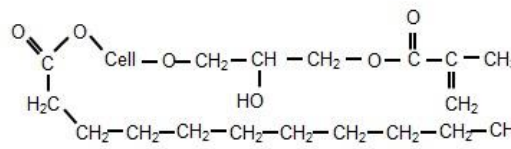

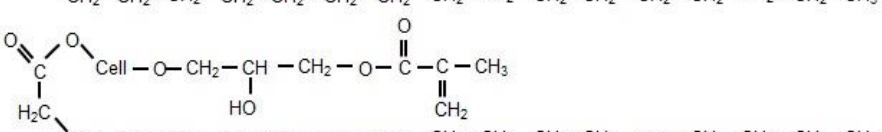

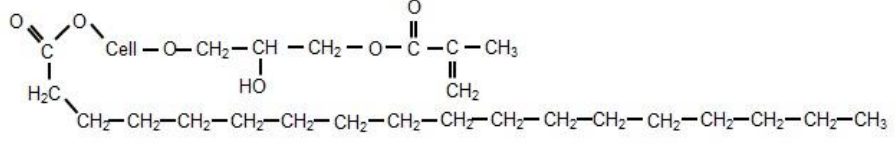

Cell-GMA-Stearin

Figure 2. Reaction scheme.

\subsection{Post-modification characterization via FT-IR} Analysis

Modified cellulose pastilles were prepared using $\mathrm{KBr}$, pestle, mortar, and hand press (Shimadzu, model 200-64175). The FT-IR spectrum was obtained from the IRsolution software in the same spectrometer used for premodification characterization (Shimadzu, model IRAffinity-1).

\subsection{Hydrophobicity and mass gain tests}

Cellulose hydrophobicity percentage before and after chemical modification was estimated according the methodology proposed by Brum et $a l .{ }^{18}$. In a separation funnel, $1.000 \mathrm{~g}$ of microcrystalline cellulose, previously weighed on analytical balance (Shimadzu, model AW220), and $20.0 \mathrm{~mL}$ of distilled water were added. Then, 20.0 $\mathrm{mL}$ of hexane was added. The mixture contained in the funnel was kept under constant stirring for 3 $\mathrm{min}$ and thereafter, allowed to stand for $5 \mathrm{~min}$. The aqueous phase was removed, and the dried material was weighed on analytical balance. The test was performed in triplicate. The same test was made with modified cellulose. Percentage hydrophobicity $(\mathrm{H} \%)$ of both materials, as well the mass gain achieved in polymeric functionalization were evaluated by the methodology described by Brum et al. ${ }^{18}$. Equation 1 was used in $\mathrm{H} \%$ calculation and Eq. 2 was used in mass gain calculation $(\mathrm{MG} \%)$. 
$H(\%)=\left(\frac{\text { material final mass }(g)}{\text { material initial mass }(g)}\right) \times 100$

$M G(\%)=\left(\frac{\text { modified material mass }(g)-\text { in microcrystalline material mass }(g)}{\text { in microcrystalline material mass }(g)}\right) \times 100$

\subsection{Oil adsorption tests}

Oily adsorption tests of microcrystalline cellulose and modified cellulose were accomplished according to methodologies proposed by Zimmermann ${ }^{24}$ and Brum et al. ${ }^{18}$. Both materials were tested for their ability to absorb three types of oils: soybean oil, diesel oil, and residual oil. An aliquot resulting from the remaining of frying oil used in the college snack bar was utilized like residual oil. The adsorption capacity was tested for volumes of $20.0 \mathrm{~mL}, 40.0$ $\mathrm{mL}$, and $60.0 \mathrm{~mL}$ of oil, individually and separately, in a beaker containing $100.0 \mathrm{~mL}$ of water and $1.000 \mathrm{~g}$ of material. For that, each oil volume was previously weighed on analytical balance. Adsorption was promoted under stirring for $10 \mathrm{~min}$ at room temperature $\left(25{ }^{\circ} \mathrm{C}\right)$, in triplicate. Subsequently, the materials were allowed to stand to drain oil excess and were weighed analytically. The adsorption efficiency was calculated by Eq. 3:

Adsorption efficiency $(\%)=\left(\frac{\text { final mass }(\text { adsorbed }+ \text { adsorbent })(g) \text {-adsorbent mass }(g)}{\text { oil mass }(g)}\right) \times 100$

\section{Results and Discussion}

\subsection{Characterization analyses}

The morphology and structure of cellulose were analyzed by SEM and FT-IR analyses. Figure 3 represents the scanning electron micrographs of microcrystalline cellulose referring to the magnification of 100, 500, 1000, and 3000 times. SEM analysis allowed analyzing the morphological structure of the polymer. It was possible to observe a characteristic surface of regular, fibrous, lignocellulosic material with an elongation of the rod type. An agglomerate appearance of sample was verified, which may have been occasioned by fixation of cellulose to the carbon tape, during the preparation of the sample for analysis in the scanning electron microscope (Fig. 3b and d).

FT-IR analysis allowed studying the structure of the polymer before and after the chemical modification. Figure 4 shows FT-IR spectra of microcrystalline cellulose and modified cellulose.
The defined band existing in range 3600 to 3000 $\mathrm{cm}^{-1}$ reports the vibrational modes of hydroxyl $(\mathrm{OH})$ groups $\left(3400-3200 \mathrm{~cm}^{-1}\right)$ and stretches of intramolecular $(\mathrm{OH})$ groups $\left(3570-3450 \mathrm{~cm}^{-1}\right)$ presents in microcrystalline cellulose molecule. Comparing both two spectra, can be seen (i) intensification of the peak in region 3000 to 2800 $\mathrm{cm}^{-1}$, suggesting the presence of new alkane $(\mathrm{CH})$ groups in the molecule $\left(2924 \mathrm{~cm}^{-1}\right)$; (ii) an intense extra carboxyl (CO) peak centered at $1716 \mathrm{~cm}^{-1}$, supporting the formation of bonding between the epoxy moiety of glycidyl methacrylate and cellulose molecule; (iii) an extra peak at $1458 \mathrm{~cm}^{-1}$, corresponding to the stretches of carboxyl (COO) groups (presents in stearin molecule), suggesting the occurrence of reaction between stearin and Cell-GMA; (iv) extra peaks in the range 1190-1070 $\mathrm{cm}^{-1}\left(1165 \mathrm{~cm}^{-1} ; 1114 \mathrm{~cm}^{-1}\right)$ supporting the hypothesis of insertion of new CO groups, arising from glycidyl methacrylate and stearin reagents, onto cellulose molecule. Similar results were evidenced by Pracella ${ }^{26}$. 

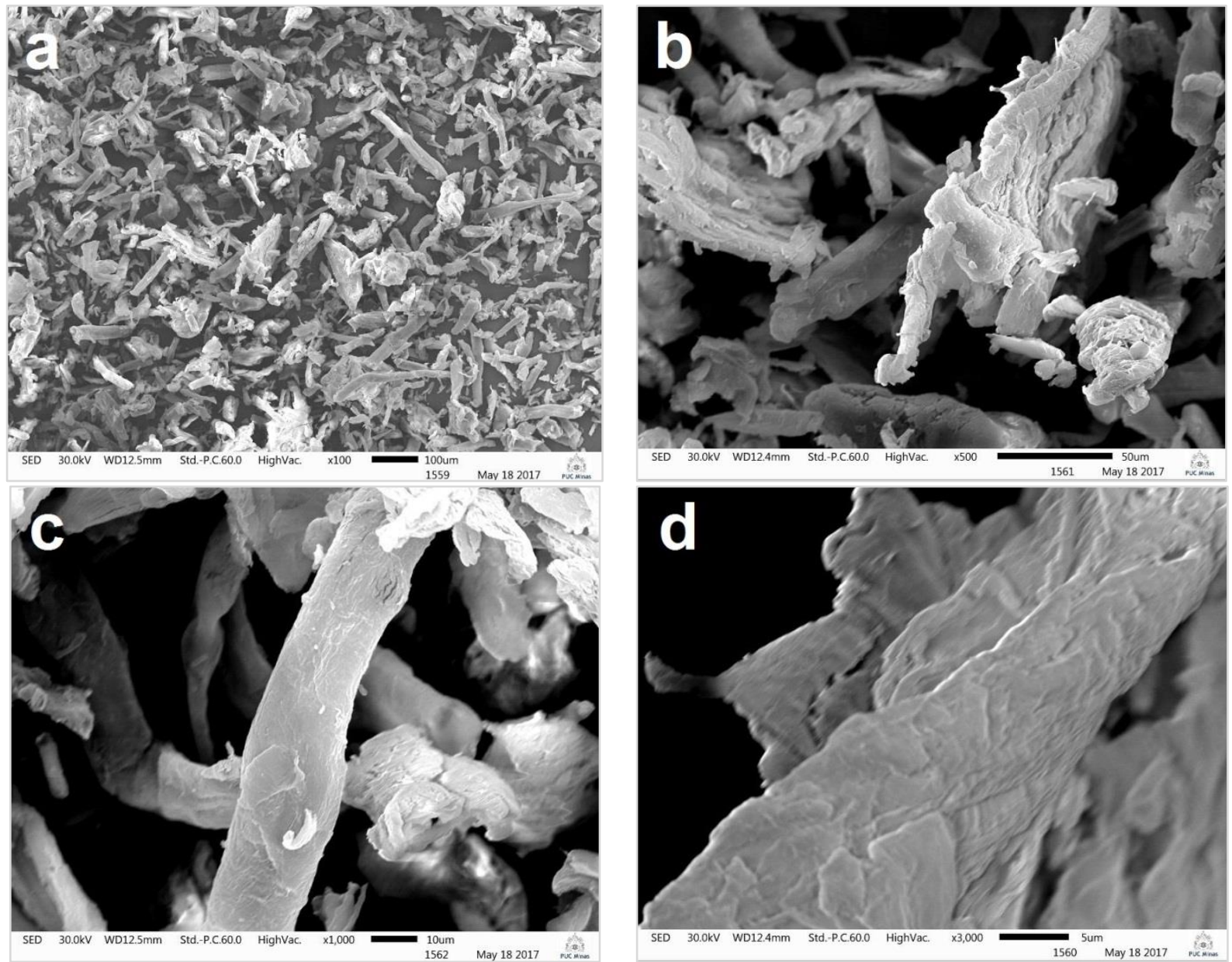

Figure 3. Scanning electron micrographs of microcrystalline cellulose (a) 100-fold magnification, (b) 500-fold magnification, (c) 1000-fold magnification, and (d) 3000-fold magnification.

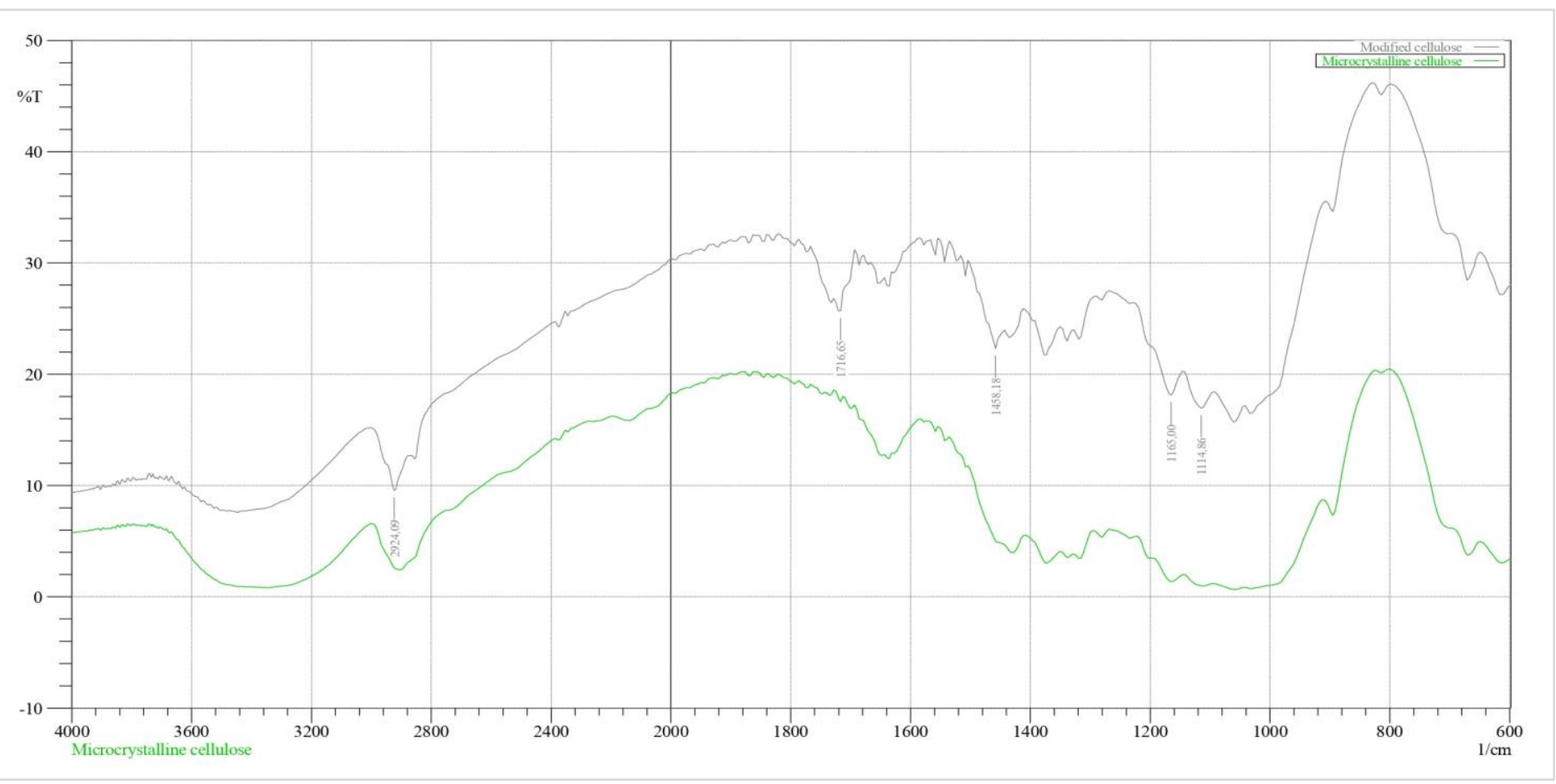

Figure 4. FT-IR spectra of microcrystalline cellulose and modified cellulose. 


\subsection{Hydrophobicity and mass gain tests}

Table 1 shows the hydrophobicity results achieved. After the hydrophobicity test, $100 \%$ of the microcrystalline cellulose mass used was in the aqueous phase, and thus, presented $0 \%$ of hydrophobicity. Zimmermann ${ }^{24}$ and Brum et al. ${ }^{18}$ also obtained the same hydrophobicity grade for microcrystalline cellulose. Meanwhile, it was possible to verify the increase of hydrophobicity for the modified material. The chemical modification route proposed using GMA/stearin suggested the insertion of alkyl groups onto cellulose molecule, enabling considerably increase the hydrophobic character of the lignocellulosic material. The increase of hydrophobicity making possible its application in the production of oil adsorbents or manufacture of composites. An average hydrophobicity grade of $78.3 \pm 0.9 \%$ was obtained, confirming the possible substitution of polar groups, particularly hydrophilic, by apolar groups (hydrophobic). Zimmermann ${ }^{24}$ also functionalized cellulose using GMA/stearin obtaining similar hydrophobicity grade $87 \pm 3 \%$.

It is expected that after reaction, the modified material will present greater molecular mass, due to the grafting of glycidyl methacrylate ( $\mathrm{MW}=$ $\left.142.15 \mathrm{~g} \mathrm{~mol}^{-1}\right)$ and stearin $\left(\mathrm{MW}=891.48 \mathrm{~g} \mathrm{~mol}^{-1}\right)$ onto cellulose molecule. In general, the higher the mass gain, the higher the alkyl groups' grafting rate $^{18}$. According to obtained results, it was observed a mass gain of $\mathrm{MG}=2.89 \%$, suggesting other indicative of the occurrence of chemical modification and, therefore, the possible substitution of hydrophilic groups by hydrophobic groups. In Tab. 2 are given the results of the mass gain test.

Table 1. Hydrophobicity test results.

\begin{tabular}{|c|c|c|c|c|c|}
\hline Material & Test & Initial mass (g) & Final mass (g) & Hydrophobicity (\%) & $\begin{array}{c}\text { Average } \\
\text { Hydrophobicity (\%) }\end{array}$ \\
\hline \multirow{2}{*}{$\begin{array}{c}\text { Microcrystalline } \\
\text { cellulose }\end{array}$} & I & & 0.001 & 0.0 & $0.0 \pm 0.0$ \\
\cline { 1 - 3 } & II & & 0.000 & 0.0 & \\
\hline \multirow{2}{*}{$\begin{array}{c}\text { Modified } \\
\text { cellulose }\end{array}$} & I & \multirow{2}{*}{1.0} & 0.001 & 0.0 & $78.3 \pm 0.9$ \\
\cline { 5 - 6 } & II & & 0.794 & 78.4 & \\
\hline
\end{tabular}

Table 2. Percentage of mass gain achieved.

\begin{tabular}{|c|c|c|}
\hline Microcrystalline Cellulose Mass (g) & Modified Cellulose Mass (g) & Mass Gain (\%) \\
\hline 36.000 & 37.041 & 2.89 \\
\hline
\end{tabular}

\subsection{Oil adsorption tests}

Oil-adsorbing materials can be used in environmental remediation of marine ecosystems contaminated by oil spills. Oily adsorption capacities of microcrystalline cellulose and modified cellulose were tested in the presence of water. Soybean oil, diesel oil, and residual oil were used because of their easy obtaining and high hydrophobicity. The obtained results in oily adsorption tests were presented in Tabs. 3 and 4.

The microcrystalline cellulose, when placed in the water/oil system, immediately passed to water, which makes its use for oil absorption in systems containing water impossible. This result was already expected based on the results obtained by the hydrophobicity test. The ability to absorb soybean, diesel and residual oils was minimal, which corroborates its majority hydrophilic character. Resembling results were evidenced by Brum et al. ${ }^{18}$.

The modification of cellulose resulted in a substantial increase in the presence of alkyl groups in its molecule, and consequently, an increase in its hydrophobicity/oleophilicity. The results demonstrated that the mass of oil adsorbed per gram of modified cellulose decreases in the order of oils residual $>$ soybean $>$ diesel, indicating the similar behavior for either oil volumes tested. This suggests a larger affinity of modified cellulose to adsorb residual oil to the detriment diesel oil. The adsorption efficiency of modified cellulose decreases in the order of $20 \mathrm{~mL}>40 \mathrm{~mL}>60 \mathrm{~mL}$ of oil volume, suggesting the smaller the amount of oil in test, bigger the adsorption effectiveness. 
Oil adsorption results of modified cellulose showed agreement with the reported by Duong ${ }^{27}$ about the relationship between viscosity and the adsorption efficiency. According to the authors, the higher the oil viscosity, the higher the adsorption rate and oil retention in the adsorbent. The adsorption efficiency of residual oil (most viscous) was higher among the analyzed oils. Already for the soybean (medium viscosity) and diesel (low viscosity) oils, the adsorption efficiency was lower, as expected. Resembling results were evidenced by Zimmermann ${ }^{24}$.

Table 3. Adsorption tests data.

\begin{tabular}{|c|c|c|c|c|c|c|c|c|c|c|c|c|c|}
\hline \multirow{3}{*}{ Oil } & \multirow{3}{*}{ Test } & \multirow{2}{*}{\multicolumn{3}{|c|}{ Oil Mass (g) }} & \multirow{2}{*}{\multicolumn{3}{|c|}{$\frac{\text { Oil Adsorbed Mass }}{\text { Microcrystalline Cellulose Gram }}$}} & \multirow{2}{*}{\multicolumn{3}{|c|}{ Oil Mass (g) }} & \multirow{2}{*}{\multicolumn{3}{|c|}{$\frac{\text { Oil Adsorbed Mass }}{\text { Modified Cellulose Gram }}$}} \\
\hline & & & & & & & & & & & & & \\
\hline & & $\begin{array}{c}20.0 \\
\mathrm{~mL}\end{array}$ & $\begin{array}{c}40.0 \\
\mathrm{~mL}\end{array}$ & $\begin{array}{c}60.0 \\
\mathrm{~mL}\end{array}$ & $20.0 \mathrm{~mL}$ & $40.0 \mathrm{~mL}$ & $60.0 \mathrm{~mL}$ & $\begin{array}{c}20.0 \\
\mathrm{~mL}\end{array}$ & $\begin{array}{c}40.0 \\
\mathrm{~mL}\end{array}$ & $\begin{array}{c}60.0 \\
\mathrm{~mL}\end{array}$ & $\begin{array}{l}20.0 \\
\mathrm{~mL}\end{array}$ & $\begin{array}{c}40.0 \\
\mathrm{~mL}\end{array}$ & $60.0 \mathrm{~mL}$ \\
\hline \multirow{3}{*}{ Soybean } & I & 17.462 & 31.004 & 49.628 & 0.079 & 0.015 & 0.024 & 17.348 & 29.078 & 51.604 & 10.874 & 16.697 & 29.348 \\
\hline & II & 16.989 & 30.076 & 49.809 & 0.081 & 0.015 & 0.022 & 17.330 & 30.934 & 48.171 & 10.474 & 19.973 & 28.141 \\
\hline & III & 17.451 & 29.200 & 50.051 & 0.080 & 0.016 & 0.023 & 17.598 & 33.000 & 49.138 & 10.976 & 20.240 & 33.727 \\
\hline \multirow{3}{*}{ Diesel } & I & 5.313 & 10.681 & 15.852 & 0.028 & 0.123 & 0.048 & 5.250 & 10.906 & 14.778 & 3.791 & 4.610 & 5.003 \\
\hline & II & 5.287 & 10.879 & 16.453 & 0.026 & 0.124 & 0.048 & 5.245 & 10.723 & 16.443 & 3.807 & 4.945 & 7.106 \\
\hline & III & 5.304 & 10.722 & 15.986 & 0.027 & 0.122 & 0.047 & 5.214 & 10.721 & 16.546 & 3.662 & 5.131 & 6.099 \\
\hline \multirow{3}{*}{ Residual } & I & 15.715 & 30.968 & 49.679 & 0.107 & 0.166 & 0.238 & 15.895 & 31.742 & 48.492 & 14.465 & 19.754 & 31.779 \\
\hline & II & 15.609 & 31.751 & 50.861 & 0.105 & 0.167 & 0.240 & 15.435 & 31.772 & 50.354 & 13.976 & 19.586 & 26.505 \\
\hline & III & 15.468 & 31.156 & 50.288 & 0.106 & 0.169 & 0.239 & 15.772 & 29.321 & 51.153 & 14.282 & 19.910 & 32.318 \\
\hline
\end{tabular}

Table 4. Adsorption efficiency results.

\begin{tabular}{|c|c|c|c|c|c|c|}
\hline \multirow{2}{*}{ Oil } & \multicolumn{3}{|c|}{ Microcrystalline Cellulose } & \multicolumn{3}{|c|}{ Modified Cellulose } \\
\hline & $20.0 \mathrm{~mL}$ oil $(\%)$ & $40.0 \mathrm{~mL}$ oil $(\%)$ & $60.0 \mathrm{~mL}$ oil $(\%)$ & $20.0 \mathrm{~mL}$ oil $(\%)$ & $40.0 \mathrm{~mL}$ oil $(\%)$ & $60.0 \mathrm{~mL}$ oil $(\%)$ \\
\hline Soybean & $0.46 \pm 0.19$ & $0.05 \pm 0.64$ & $0.05 \pm 0.15$ & $62 \pm 1$ & $61 \pm 4$ & $61 \pm 7$ \\
\hline Diesel & $0.51 \pm 0.01$ & $1.14 \pm 0.07$ & $0.30 \pm 0.22$ & $84 \pm 1$ & $52 \pm 3$ & $42 \pm 5$ \\
\hline Residual & $0.01 \pm 0.09$ & $0.01 \pm 0.29$ & $0.005 \pm 0.418$ & $90.7 \pm 0.3$ & $64 \pm 3$ & $61 \pm 7$ \\
\hline
\end{tabular}

\section{Conclusions}

SEM and FT-IR analyses results obtained for microcrystalline cellulose allowed to recognize the morphological structure and the functional groups of the studied polymer. The chemical modification route of the polymer structure via GMA/stearin reactions suggested the possible insertion of hydrophobic groups onto the cellulose molecule, corroborated by the reach an average hydrophobicity grade of $78.3 \pm 0.9 \%$ and a mass gain of $\mathrm{MG}=2.89 \%$. FT-IR analysis results of modified cellulose enabled to identify appeared modifications in the chemical structure of the polymer, reinforcing the hypothesis of successful grafting of GMA and stearin onto the structure. The oily adsorption tests proved a satisfactory capacity of the modified cellulose to adsorb small amounts of viscous oils, like residual oil. It is expected which the potential of the oil-adsorbing material can be availed in the development of improvements and solutions of environmental remediation of marine ecosystems contaminated by oil spills.

\section{Acknowledgments}

The authors would like to acknowledge Thaís Munique Sales Leite Hipólito of Laboratory of Instrumental Analyses of the Pontifical Catholic University of Minas Gerais for her collaboration and technician support.

\section{References}

[1] Bisceglia, L., Poluição e contaminação ambiental: a extração de petróleo e seus reflexos no meio ambiente, Jusbrasil

(2016). https://luisabisceglia.jusbrasil.com.br/artigos/23526039 4/poluicao-e-contaminacao-ambiental-a-extracao-depetroleo-e-seus-reflexos-no-meio-ambiente.

[2] Cantagallo, C., Milanelli, J. C. C., Dias-Brito, D., Limpeza de ambientes costeiros brasileiros contaminados por petróleo: uma revisão, Pan-American Journal of Aquatic Sciences 2 (1) (2007) 1-12. http://panamjas.org/pdf_artigos/PANAMJAS_2(1)_112.pdf.

[3] Lanza, A., Como a gestão ambiental pode evitar desastres naturais, Instituto Brasileiro de Certificação Ambiental IBRACAM (2005). 
https://ibracam.com.br/blog/como-a-gestao-ambientalpode-evitar-desastres-naturais.

[4] Carneiro, L., Naidin, H., Depois do óleo derramado: legislação é mais punitiva que preventiva, O Globo (2012).

[5] Craig, A. P. de L., Sena, E., Magalhães, L., Krause, M. C., Neves, P. R., Silva, M. de J., Técnicas de limpeza de vazamentos de petróleo em alto mar, Cadernos de Graduação - Ciências Exatas e Tecnológicas 1 (1) (2012) 75-86. https://periodicos.set.edu.br/index.php/cadernoexatas/a rticle/view/207.

[6] Greenpeace, Desastre no Golfo do México completa cinco anos, Greenpeace Brasil (2015). http://www.greenpeace.org/brasil/blog/desastre-nogolfo-do-mexico-completa-cinco-anos/.

[7] Huff, V. S. M., A responsabilidade ambiental no vazamento de petróleo no mar, Âmbito Jurídico (2016). http://www.ambito-

juridico.com.br/site/?n_link=revista_artigos_leitura\&ar tigo_id=16866.

[8] Fonseca, L., 4 aplicações de microrganismos na indústria do petróleo que você não conhecia, Portal Tratamento de Água (2017). http://www.tratamentodeagua.com.br/microrganismosindustria-petroleo/.

[9] Szewczyk, S. B. O., Processos envolvidos em um derramamento de óleo no mar, Seminário e Workshop em Engenharia Oceânica (SEMENGO) (2006).

[10] Albertini, S., Carmo, L. F. do, Prado Filho, L. G. do, Utilização de serragem e bagaço de cana-de-açúcar para adsorção de cádmio, Ciência e Tecnologia de

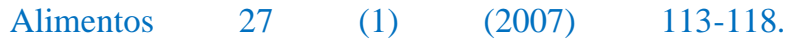
https://doi.org/10.1590/S0101-20612007000100020.

[11] Almagro, A. S., Meneguelo, A. P., Mendes, A. N. F., Rocha, S. M. S., Estudo do uso de casca de coco como bioadsorvente para a remoção de óleos e graxas de efluentes, XXXVII Congresso Brasileiro de Sistemas Particulados $2 \quad$ (1) (2015) 976-982. https://doi.org/10.5151/ENEMP2015-PS-497.

[12] Pimentel, P. M., Silva Junior, C. N., Melo, D. M. A., Melo, M. A. F., Maldonado, G., Henrique, D. M., Caracterização e uso de xisto para adsorção de chumbo (II) em solução, Cerâmica 52 (323) (2006) 194-199. https://doi.org/10.1590/S0366-69132006000300013.

[13] Santos, C. P. F. dos, Melo, D. M. A., Melo, M. A. F., Vitor Sobrinho, E., Caracterização e usos de argilas bentonitas e vermiculitas para adsorção de cobre (II) em solução, Cerâmica 48 (308) (2002) 178-182. https://doi.org/10.1590/S0366-69132002000400002.

[14] Klemm, D., Philipp, B., Heinze, T., Heinze, U., Wagenknecht, W., Comprehensive cellulose chemistry: fundamentals and analytical methods, Wiley-VCH Verlag: Weinheim, Germany, 1998. https://doi.org/10.1002/3527601929.

[15] Lengowski, E. C., Muniz, G. I. B. de, Nisgoski, S., Magalhães, W. L. E., Avaliação de métodos de obtenção de celulose com diferentes graus de cristalinidade, Scientia Forestalis 41 (98) (2013) 185-194. http://ainfo.cnptia.embrapa.br/digital/bitstream/item/87 065/1/Wash-avaliacao-de-metodos-de-obtencao-decelulose-com-diferentes-graus-de-cristalinidade.pdf.

[16] Oliveira, M. de, Carminatti, C. A., Produção de celulose bacteriana em cultura estática utilizando diferentes fontes de carbono, Trabalho de Conclusão de Curso (Graduação) - Universidade Federal de Santa Catarina, Centro Tecnológico de Joinville, Bacharelado em Ciência e Tecnologia, 2016. https://repositorio.ufsc.br/xmlui/handle/123456789/171 571.

[17] Costa, S. A., Pozzani, L. S., Costa, S. M., Rogero, S. O., Cruz, A. S., Pessoa Junior, A., Fibras têxteis híbridas à base de celulose e quitosana para aplicações médicas, $18^{\circ}$ CBECIMAT - Congresso Brasileiro de Engenharia e Ciência dos Materiais (2008) 9464-9471. http://texcontrol.com.br/wp-

content/uploads/2016/02/Fibras-texteis-hibridas-abase-de-celulose-e-quitosana-para-aplicacoes-medicasarea-hospitalar.pdf.

[18] Brum, S. S., Oliveira, L. C. A. de, Bianchi, M. L., Guerreiro, M. C., Oliveira, L. K. de, Carvalho, K. T. G., Síntese de acetato de celulose a partir da palha de feijão utilizando $N$-bromossuccinimida (NBS) como catalisador, Polímeros 22 (5) (2012) 447-452. https://doi.org/10.1590/S0104-14282012005000061.

[19] Ferreira, B. C. S., Gil, L. F., Gurgel, L. V. A., Freitas, R. P., Obtenção de um novo derivado carboxilado de celulose microcristalina: uma síntese fácil e sem solvente, Revista Virtual de Química 9 (1) (2017) 431-451. https://doi.org/10.21577/19846835.20170024 .

[20] Kalashnikova, I., Bizot, H., Cathala, B., Capron, I., Modulation of cellulose nanocrystals amphiphilic properties to stabilize oil/water interface, Biomacromolecules $13 \quad$ (1) (2012) 267-275. https://doi.org/10.1021/bm201599j. 
[21] Macedo, V., Barros, A. R., Zimmermann, M. V. G., Scienza, L. C., Zattera, A. J., Hidrofobização de fibras de celulose de pinus e sua influência na sorção de óleo, $21^{\circ}$ CBECIMAT - Congresso Brasileiro de Engenharia e Ciência dos Materiais (2014) 7785-7792. http://www.metallum.com.br/21 cbecimat/CD/PDF/415 -005.pdf.

[22] Mohamed, M. A., Salleh, W. N. W., Jaafar, J., Ismail, A. F., Mutalib, M. A., Jamil, S. M., Feasibility of recycled newspaper as cellulose source for regenerated cellulose membrane fabrication, Journal of Applied Polymer Science 132 (43) (2015) 1-10. https://doi.org/10.1002/app.42684.

[23] Oliveira, L. K., Castro, S. de F., Bertechini, A. G., Lima, E. M. C., Espósito, M., Bianchi, M. L., Desenvolvimento de materiais adsorventes de óleos a partir de resíduos do beneficiamento do café e sua aplicação na ração para aves, Revista Brasileira de Saúde e Produção Animal 13 (4) (2012) 902-911. https://doi.org/10.1590/S1519-99402012000400018.

[24] Zimmermann, M. V. G., Zattera, A. J., Santana, R. M. C., Modificação química da celulose para utilização como adsorvente de óleos hidrofóbicos, $4^{\circ}$ Congresso Internacional de Tecnologias para o Meio Ambiente (2014)

$1-7$. http://siambiental.ucs.br/congresso/getArtigo.php?id=1 86\&ano=_quarto.

[25] Potulski, D. C., Viana, L. C., Muniz, G. I. B. de, Andrade, A. S. de, Klock, U., Caracterização de nanofilmes de celulose nanofibrilada obtida em diferentes consistências, Scientia Forestalis 44 (110) (2016)

361-372. https://doi.org/10.18671/scifor.v44n110.09.

[26] Pracella, M., Haque, M. M.-U., Alvarez, V., Compatibilization and properties of EVA copolymers containing surface-functionalized cellulose microfiber, Macromolecular Materials and Engineering 295 (10) (2010) 949-957. https://doi.org/10.1002/mame.201000175.

[27] Duong, H. T. T., Burford, R. P., Effect of foam density, oil viscosity, and temperature on oil sorption behavior of polyurethane, Journal of Applied Polymer $\begin{array}{lllll}\text { Science } & 99 & \text { (1) } & \text { (2005) } & \text { 360-367. }\end{array}$ https://doi.org/10.1002/app.22426. 